This item was submitted to Loughborough's Research Repository by the author.

Items in Figshare are protected by copyright, with all rights reserved, unless otherwise indicated.

\title{
Electric vehicle cold start range estimation through battery-in-loop simulations within a virtual driving environment
}

PLEASE CITE THE PUBLISHED VERSION

https://doi.org/10.4271/2020-01-0453

\section{LICENCE}

CC BY-NC-ND 4.0

\section{REPOSITORY RECORD}

Sarmiento-Carnevali, Maria, Ashley Fly, and P Piecha. 2020. "Electric Vehicle Cold Start Range Estimation Through Battery-in-loop Simulations Within a Virtual Driving Environment”. Loughborough University. https://hdl.handle.net/2134/12280484.v1. 


\title{
Electric vehicle cold start range estimation through battery-in-loop simulations within a virtual driving environment
}

\author{
Author, co-author (Do NOT enter this information. It will be pulled from participant tab in \\ MyTechZone) \\ Affiliation (Do NOT enter this information. It will be pulled from participant tab in MyTechZone)
}

\begin{abstract}
Lithium-ion (Li-ion) batteries have become a research focus in the field of electric and hybrid electric vehicles, due to key advantages such as high specific energy, high energy density and low selfdischarge rate in comparison with other battery technologies. Nevertheless, key issues involving safety, performance, cost, charging time and durability restrict mass market adoption of electric vehicles. Cold-temperature operation of Li-ion batteries is currently a subject of major research efforts. The effects of low temperature reduce the available energy of the battery and increase its internal impedance. Moreover, Li-ion batteries experience serious degradation mechanisms at low temperatures, strongly affecting performance, which poses difficulties for cold-climate countries. In this work, a battery-in-the-loop experiment has been set up to estimate and analyze Li-ion battery cold start ranges at temperatures down to $-40{ }^{\circ} \mathrm{C}$. This experimental setup is connected to the open integration and test platform CarMaker from IPG Automotive to evaluate cold start range both through standardized automotive duty cycles and within a virtual test environment designed to replicate real-world test driving. In addition, a non-isothermal equivalent circuit battery model has been developed in CarMaker for Simulink and validated against experimental data. Effects of cold temperatures on the capacity and power fade of Li-ion battery technology are studied, as well as important thermal aspects, including effects of changing battery heat transfer coefficient to replicate different thermal management strategies. Range discrepancies between standardized duty cycles and a representative driving environment are also explored. Overall, this work contributes to identify key improvements in Li-ion battery thermal management for performance and durability enhancement during cold start.
\end{abstract}

\section{Introduction}

Lithium-ion batteries feature high energy density, high discharge power and long service life. Their emerging application to electric vehicles makes them a promising solution for challenges of environmental preservation and resource conservation. With low selfdischarge rate and a wide range of safe operating temperatures (charging: $0^{\circ} \mathrm{C} \sim 45^{\circ} \mathrm{C}$, discharging: $-20^{\circ} \mathrm{C} \sim 60^{\circ} \mathrm{C}$ ), Li-ion batteries are preferred over other mature battery technologies such as lead acid and nickel-cadmium (NiCd). A Li-ion battery consists of an anode, cathode, separator, electrolyte and two current collectors (positive and negative). The anode and cathode store lithium, whilst the electrolyte carries positively charged lithium ions from the anode to the cathode and vice versa through the separator. The performance of Li-ion batteries degrades at temperatures below $0{ }^{\circ} \mathrm{C}[1]$. With the decrease of temperature, the viscosity of the electrolyte will increase, which will reduce the ionic conductivity. The internal resistance will subsequently rise due to the increase in the impedance of the directional migration of chemical ions. In addition, Li-ion batteries will show slow chemicalreaction activity and charge transfer velocity [2] at cold temperatures, which leads to the decrease of ionic conductivity in the electrolytes [3]. Such decrease will result in increased polarization effects and the reduction of energy and power capability, and sometimes even performance failure. Moreover, effects such as lithium plating occur mainly at low temperatures. The cold condition triggers the polarization of anodes causing the potential of graphite to approach that of lithium metal plating, which slows down the lithiumion intercalation into the anodes during charging process [4]. Furthermore, the lithium plating exists in the form of dendrite, which may penetrate the separators and result in the internal short-circuit [5]. Previous studies have shown an average 20\% decrease in battery available capacity when the operating temperature decreases from $25^{\circ} \mathrm{C}$ down $-15^{\circ} \mathrm{C}$ [6]. Charging Li-ion batteries, including regenerative braking, at low temperatures is even more challenging due to lithium plating (charging is not recommended at subzero battery temperatures). These limitations pose major obstacles for mass market adoption of electric vehicles, since failure to meet load demand upon certain climate conditions is unacceptable in automotive applications. Therefore, cold-temperature operation of Li-ion batteries is currently a subject of major research efforts including improvement of battery materials [7-10] and operating conditions/management strategies [11].

Battery thermal management strategies studied in the literature can be separated into self-heating, through battery discharge, and heating from an external energy source, such as mains electricity [12]. A challenge when developing thermal management strategies for electric vehicles is the highly transient load demand and external factors such as traffic, vehicle payload and driver behavior. These factors are often not considered in existing cold start studies which generally focus on thermal response to controlled constant current demand [13], making it difficult to translate results into an estimated vehicle range.

In this work, a battery-in-the-loop experiment has been set up to estimate and analyze Li-ion battery cold start ranges under representative automotive duty cycles at temperatures down to $-40^{\circ} \mathrm{C}$. This experiment utilizes CarMaker to simulate the vehicle driver, electric vehicle powertrain and a virtual driving environment. Experimental data is used to develop and validate a non-isothermal equivalent circuit battery model. This model is then used to

Page 1 of 9

$10 / 19 / 2016$ 
replicate/analyze different thermal management strategies by changing battery heat transfer coefficient. The paper is organized as follows: Section 'Experimental Setup and Procedure' describes the overall battery-in-loop experiment and duty cycles run upon the battery-inloop setup. Section 'Analysis of Experimental Results' presents experimental data obtained from running various duty cycles upon battery-in-loop setup and analysis of results, including comments on range discrepancies between standardized duty cycles and a representative driving environment. Section 'Li-ion Cell Model Development' covers the details of equivalent circuit model implemented and validated. Sections 'Model-based Thermal Analysis' and 'Model-based Driver Analysis' present simulation results using the validated cell model to investigate the effect of battery temperature, and driver settings on estimated vehicle range. Finally, Section 'Concluding Remarks' offers a summary of this work, highlights, as well as ongoing and future work.

\section{Experimental Setup and Procedure}

This study focuses on a single Li-ion battery cell assumed to be representative and scalable up to a module/pack level (i.e. ignoring cell to cell variation). The cell used in this work is a Sony VTC6 18650 cylindrical cell which utilizes the widely employed $\mathrm{LiNiCoAlO}_{2}$ chemistry (Nickel-Cobalt-Aluminum /NCA) for the positive electrode and graphite with added silicon for the negative electrode [14]. Specifications of the Li-ion cell used in the experiment are presented in Table 1:

Table 1. Sony VTC6 Li-ion cell specifications.

\begin{tabular}{|l|l|}
\hline Property & Value \\
\hline Nominal capacity & $3000 \mathrm{mAh}$ \\
\hline Nominal voltage & $3.6 \mathrm{~V}$ \\
\hline Upper cut-off voltage & $4.2 \mathrm{~V}$ \\
\hline Lower cut-off voltage & $2.5 \mathrm{~V}$ \\
\hline $\begin{array}{l}\text { Operating temperature } \\
\text { (recommended) }\end{array}$ & $\begin{array}{l}\text { Charging: } 0^{\circ} \mathrm{C}-45^{\circ} \mathrm{C} \\
\text { Discharging: }-20^{\circ} \mathrm{C}-60^{\circ} \mathrm{C}\end{array}$ \\
\hline
\end{tabular}

In this work the cell is exposed to temperatures ranging from $20^{\circ} \mathrm{C}$ down to $-40^{\circ} \mathrm{C}$, both through standardized automotive duty cycles and within a simulated 'real-world' driving environment, in order to explore cold start performance and derive vehicle range estimations. Practical applications require multiple cells rather than single cells, which have different external thermal boundary conditions. This contribution focuses on the behavior of single cells at different initial temperature conditions, but experimental results can be applied to the modelling of multi-cell packs by changing the external heat transfer coefficient and ambient temperature to represent a cell within a pack.

\section{Li-ion Cell Test Setup}

A climatic chamber (Weisstechnik C1500) was used to recreate ambient temperature conditions ranging from $20^{\circ} \mathrm{C}$ down to $-40^{\circ} \mathrm{C}$. Two type-K thermocouples were connected to each end of the cell within the chamber, with Kapton tape for surface temperature measurements using a PICO TC-08 datalogger. A Keithley SourceMeter ${ }^{\circledR} 2461$ source measure unit (SMU) was connected to the cell being tested through a high current aluminum fixture in four-wire test mode. The experimental hardware is connected to CarMaker for Simulink software using LabVIEW. The SMU receives current demands from the CarMaker simulation software, applies them to the physical battery under test and returns the measured voltage to the Page 2 of 9 simulation. Thus, the CarMaker software can control the battery and model the rest of the vehicle. In this case, the simulation corresponds to an electric vehicle driving in a virtual driving environment. The vehicle dynamics, electric motor and control strategy are all simulated and connected to the physical battery in the chamber. Figure 1(a) depicts the described experimental setup. Figure 1(b) shows a schematic of interconnection between experimental setup elements, including input and output variables.

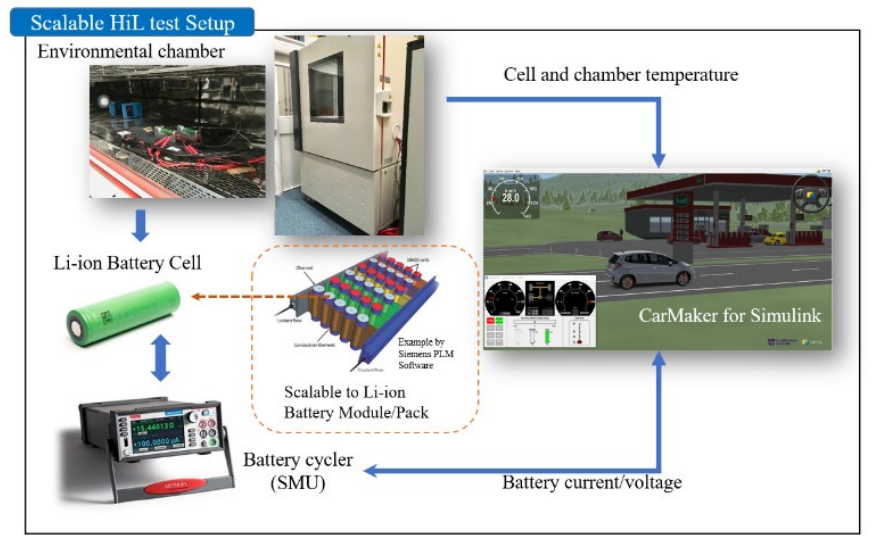

(a)

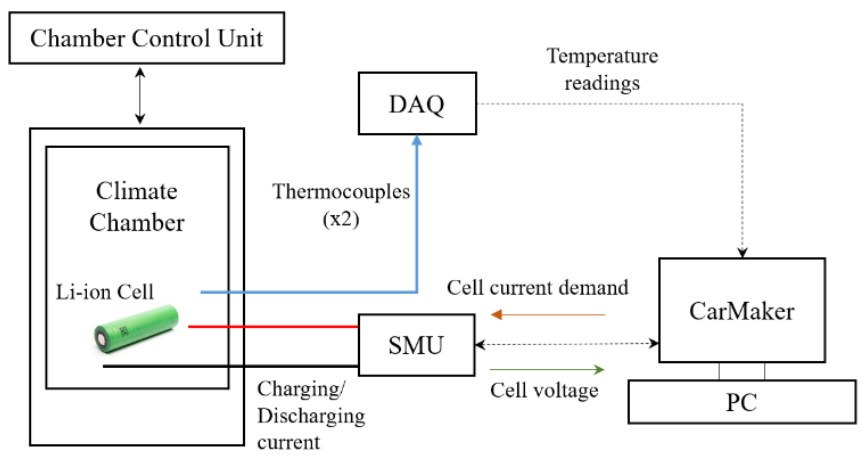

USB connection

(b)

Figure 1. (a) Experimental setup block diagram. (b) Interconnection and signal specification between all setup elements.

\section{Description of Reference Vehicle and Battery Pack}

A generic electric passenger vehicle, similar in dimensions and battery capacity to a Nissan Leaf, was parameterized and implemented into Carmaker, according specifications shown in Table 2. The powertrain comprises one electric motor, high voltage battery and corresponding powertrain control units. The battery control unit (BCU) sends the current demand signal to the battery according to power demand by the electric motor and receives the battery voltage signal from the battery. The BCU only permits regenerative braking when the cell surface temperature is above $5{ }^{\circ} \mathrm{C}$, to avoid the risk of lithium plating during charging.

\section{Description of Driving Cycles}

Three different duty cycles were considered to evaluate cell performance at various temperature levels under analysis. The first cycle corresponds to the Worldwide Harmonized Light Vehicle Test 
Procedure (WLTP) - Class 3 test for hybrid and electric vehicles. This cycle accounts for $23.25 \mathrm{~km}$ of low to average maximum speeds. The second cycle corresponds to GPS data collected from a Real Driving Emissions (RDE) Test performed at HORIBA MIRA, Nuneaton, UK and is available within CarMaker as a product example. This cycle accounts for $85.03 \mathrm{~km}$ of low to average maximum speeds, stops and up/down elevation changes. Finally, a third cycle has been tested to account for city, countryside and motorway driving. This Real Driving Generated (RDG) cycle has been implemented within the CarMaker test environment and covers $10.7 \mathrm{~km}$. Unlike the WLTP which has a defined velocity profile, the RDE and RDG cycles are defined by the route the vehicle takes, meaning that the influence of external factors such as additional traffic or driver aggression on vehicle range can be studied. Figure 2 presents the velocity profiles of the three cycles, where the RDE and RDG cycles use the standard IPG-driver model implemented in Carmaker.

Table 2. Carmaker electric vehicle model specifications.

\begin{tabular}{|l|l|}
\hline Property & Value \\
\hline Frontal area & $2.3 \mathrm{~m}^{2}$ \\
\hline Curb mass & $1700 \mathrm{~kg}$ \\
\hline Drag coefficient & 0.28 \\
\hline Air density & $1.225 \mathrm{~kg} / \mathrm{m}^{3}$ at $15^{\circ} \mathrm{C}$ \\
\hline Battery pack energy & $60 \mathrm{kWh}$ \\
\hline Battery pack voltage & $403.2 \mathrm{~V}$ \\
\hline Battery pack capacity & $150 \mathrm{Ah}$ \\
\hline Total number of cells & 5600 \\
\hline Number of cells in series & 112 \\
\hline Number of cells in parallel & 50 \\
\hline Nominal cell energy & $10.8 \mathrm{Wh}$ \\
\hline Mechanical power & $150 \mathrm{~kW}$ \\
\hline
\end{tabular}

\section{Experimental Procedure}

The WLTP cycle was run under temperature conditions ranging from $20^{\circ} \mathrm{C}$ down to $-40^{\circ} \mathrm{C}$ by $10^{\circ} \mathrm{C}$ decrements each time. The RDE and the RDG cycles were run at $20^{\circ} \mathrm{C}$ and $0^{\circ} \mathrm{C}$. As described in the previous section, the vehicle BCU simulated in CarMaker establishes power demand to the battery pack as well as regenerative braking recharge periods. Discharge/charge current to the battery pack demanded by the simulation is scaled down to a single cell, applied to the physical cell in the chamber, then the measured voltage scaled back up to the pack level. The same cell was used for all tests. Two $\mathrm{C} / 6$ charge/discharge cycles were performed before and after testing to condition the cell before testing and ensure results were not adversely influenced by cell degradation.

Prior to each test the cell is charged at $20^{\circ} \mathrm{C}$ to $4.2 \mathrm{~V}$ using a constant current/constant voltage (CCCV) charging protocol at $0.5 \mathrm{~A}(\mathrm{C} / 6)$ and $100 \mathrm{~mA}$ current cut off. The cell is then soaked at the desired temperature for 12 hours before starting the test. During the test the battery-in-loop simulation is run over the chosen duty cycle multiple times until the cell reaches its lower voltage cut-off limit of $2.5 \mathrm{~V}$. The cut-off limit represents the point at which the battery can no longer meet the power demand of the vehicle. Once the cell is discharged, the recorded velocity of the car is integrated over the test to find total distance attained and estimate vehicle range.
For every test, two measures of the cell temperature are recorded, as well as cell current and voltage. In addition, CarMaker can store vehicle velocity and several other variables associated to the car, such as motor electric power. All measurements were taken at $10 \mathrm{~Hz}$.

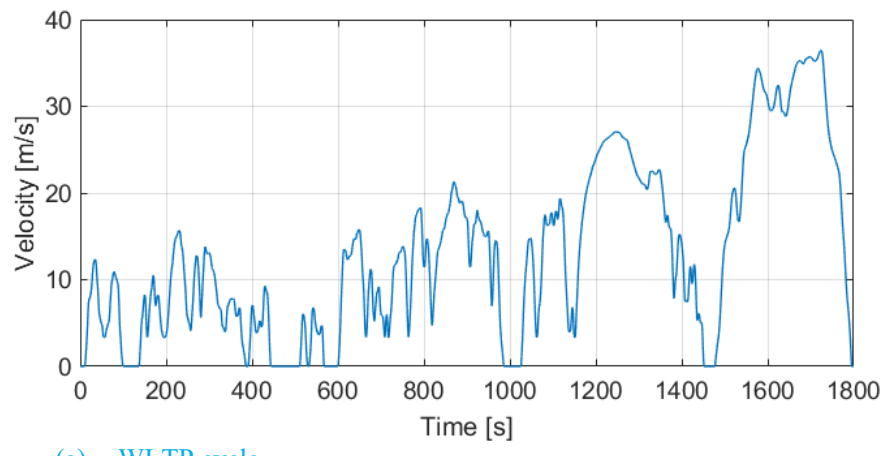

(a) WLTP cycle

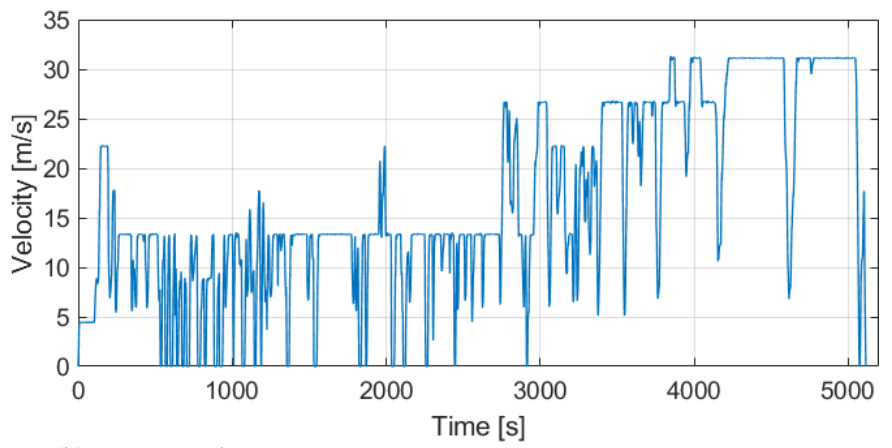

(b) RDE cycle

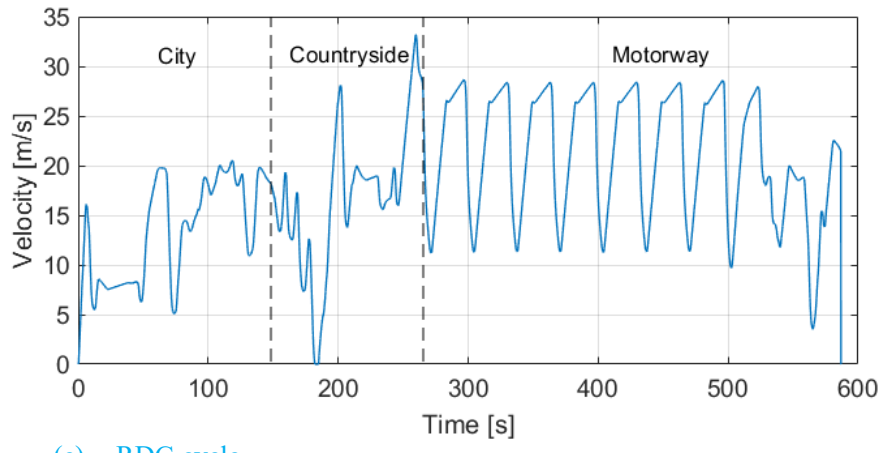

(c) RDG cycle

Figure 2. Vehicle duty cycles under study. (a) WLTP cycle: distance $23.25 \mathrm{~km}$ / time 1800 s. (b) RDE-MIRA cycle: distance 85.03 km / time 5114s. (c) RDG cycle: distance $10.7 \mathrm{~km} /$ time $587 \mathrm{~s}$.

\section{Analysis of Experimental Results}

Using the battery-in-loop setup and vehicle parameters described previously, range estimation tests were conducted for the three duty cycles at various temperatures. Figure 3 shows the cell voltage profiles for WLTP tests both at $20^{\circ} \mathrm{C}$ and $-20^{\circ} \mathrm{C}$. At $20^{\circ} \mathrm{C}$, it takes almost 13 WLTP cycles ( $1 / 2$ hour per cycle) to see the cell reach the voltage cutoff limit of $2.5 \mathrm{~V}$. At $-20^{\circ} \mathrm{C}$ the figure clearly shows the effects of temperature on usable cell capacity. The cell reaches the low voltage limit earlier during the $-20^{\circ} \mathrm{C}$ test, which indicates approximately $13.4 \%$ loss of usable capacity. In addition, the voltage profile magnitude at $-20^{\circ} \mathrm{C}$ reflects a higher value of ionic resistance, at subzero temperatures. 


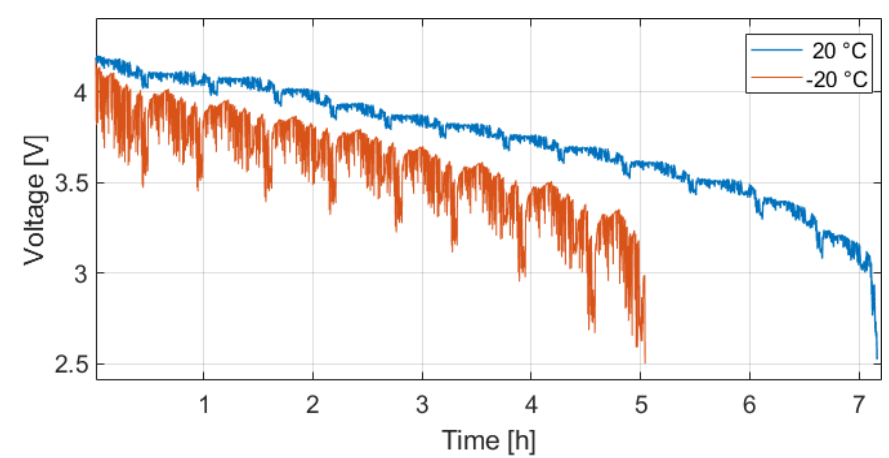

Figure 3. WLTP driving cycle test: voltage profile vs time at $20^{\circ} \mathrm{C}$ and $-20{ }^{\circ} \mathrm{C}$

With the decrease of temperature, the internal resistance of the cell subsequently rises due to the increase in electrolyte ionic resistance. Such a temperature decrease results in increased polarization effects, thus larger voltage losses are seen in Figure 3 during the discharge cycle. This also causes cell voltage to reach the minimum voltage safety limit sooner than at normal (ambient) operating temperatures, resulting in reduction of energy and power capability, and sometimes even performance failure. Figure 4 shows the C-rate profiles for both WLTP tests, where C-rate is calculated using the nominal rated capacity. In both cases the cell reaches its lower voltage limit during the high or extra high speed section of the WLTP, where current demand and hence voltage drop is highest. It can also be seen that regenerative braking is not present in figure 4(b) as the cell surface temperature remains below $5{ }^{\circ} \mathrm{C}$ throughout the test.

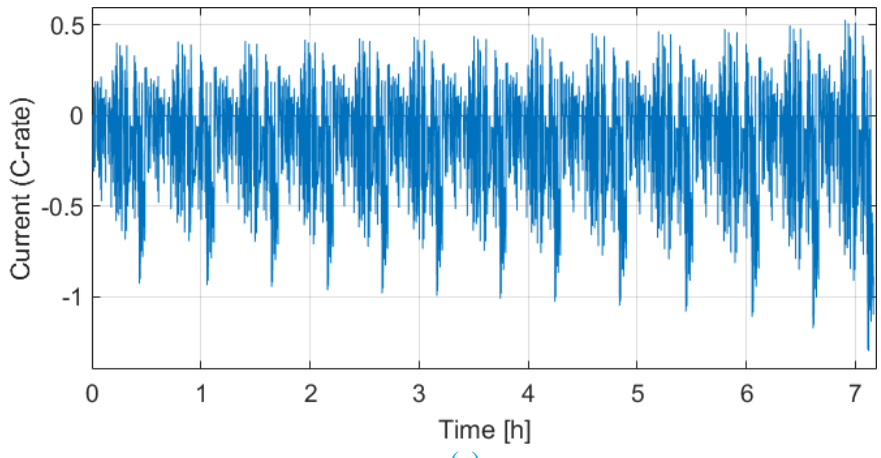

(a)

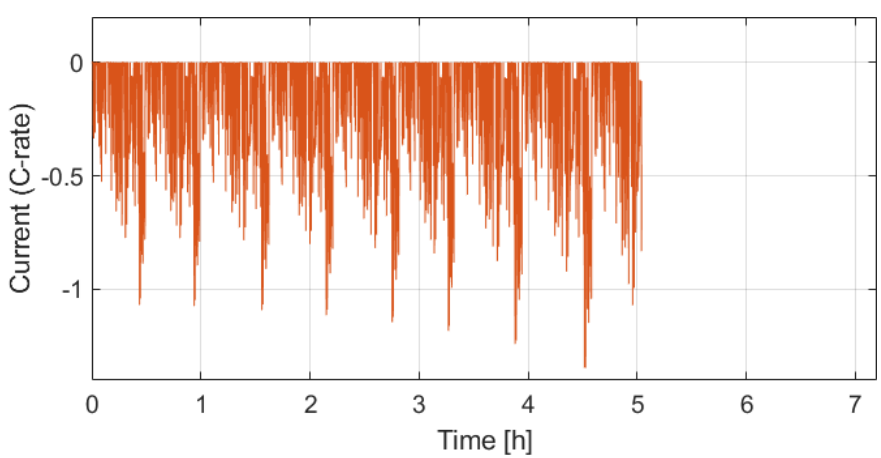

(b)

Figure 4. WLTP driving cycle test: C-rate profiles at (a) $20{ }^{\circ} \mathrm{C}$ and (b) $-20{ }^{\circ} \mathrm{C}$.

Figure 5 presents the influence of reducing ambient temperature on measured cell capacity under WLTP regime. For comparison, the measured capacity of an identical cell under $\mathrm{C} / 6$ constant current discharge is also presented. In both cases, a relatively linear reduction in capacity is seen between $20{ }^{\circ} \mathrm{C}$ and $-20{ }^{\circ} \mathrm{C}$ followed by a sharp capacity reduction as temperature drops further. This is likely because the Ethylene Carbonate (EC) component of the electrolyte precipitates below $-20{ }^{\circ} \mathrm{C}$, significantly reducing the electrolyte ionic conductivity [15]. Comparing the battery-in-loop WLTP capacity to the C/6 constant current discharge shows very good agreement from $20^{\circ} \mathrm{C}$ to $-20{ }^{\circ} \mathrm{C}$ before deviating further at lower temperatures. Below this temperature level, with increased electrolyte resistance, the higher currents of the WLTP lead to the lower voltage threshold being exceeded and a reduced useable capacity. This implies that, for the cell and vehicle tested, constant current capacity tests can be representative of range over the WLTP cycle down to $-20{ }^{\circ} \mathrm{C}$. At $-40{ }^{\circ} \mathrm{C}$ the cell was unable to provide sufficient power for the first major acceleration of the cycle before reaching its lower voltage threshold.

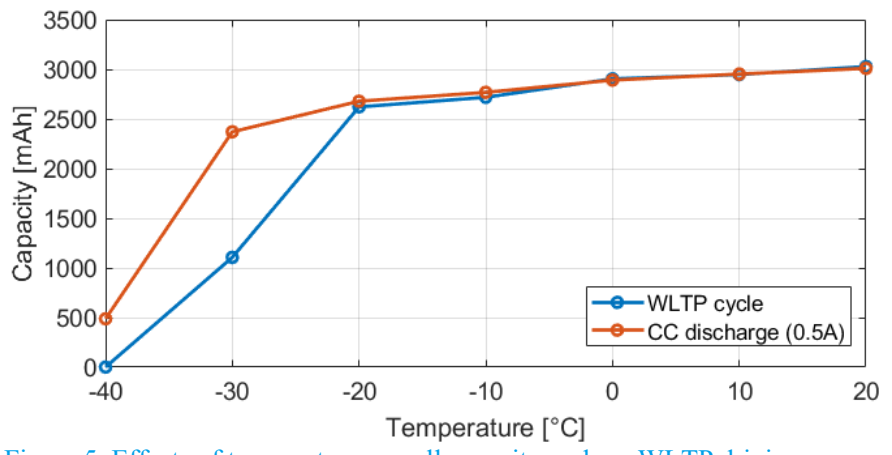

Figure 5. Effects of temperature on cell capacity under a WLTP driving scenario, as well as a constant current discharge test at $\mathrm{C} / 6$.

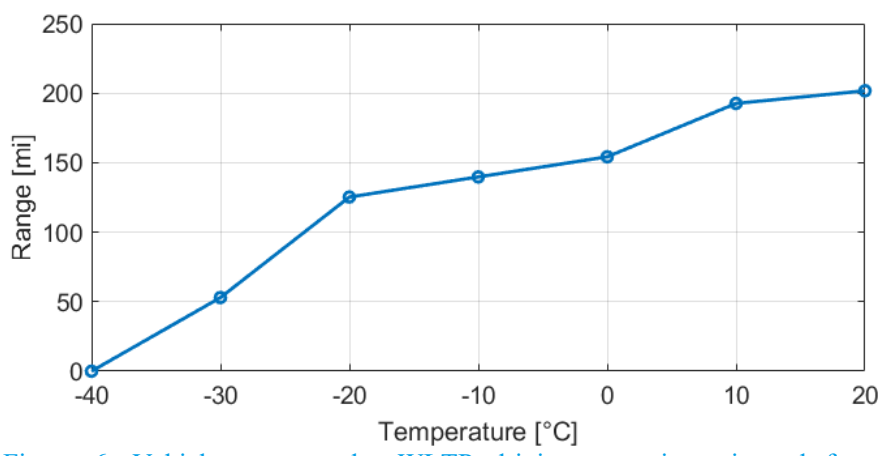

Figure 6. Vehicle range under WLTP driving scenario estimated from experimental cell study.

Figure 6 shows the effect of temperature on vehicle range using the WLTP, where a $30.9 \%$ reduction in range is seen when the initial temperature is reduced from $20{ }^{\circ} \mathrm{C}$ to $-10{ }^{\circ} \mathrm{C}$. This range reduction is caused only due to the propulsion effort of the vehicle and does not include ancillary loads such as cabin heating. Unlike the capacity plot of figure 5, a drop-in range is seen from $10^{\circ} \mathrm{C}$ to $0{ }^{\circ} \mathrm{C}$ due to the $\mathrm{BCU}$ not permitting the use of regenerative braking at low temperatures. During all tests presented, the measured surface temperature of the battery did not increase beyond $5{ }^{\circ} \mathrm{C}$ from its initial starting temperature.

To evaluate the influence of different duty cycles, identical tests were performed at $20^{\circ} \mathrm{C}$ and $0{ }^{\circ} \mathrm{C}$ using the RDE and RDG cycles described previously. Figure 7 shows the range for these tests. Range reduction between these two temperatures was $23.55 \%, 17.23 \%$ and $17.21 \%$ for the WLTP, RDE and RDG tests respectively. The reduction of range during the RDE and RDG cycles in comparison to WLTP at both temperatures is likely due to higher C-rates caused by increased acceleration rates and the inclusion of altitude changes. Overall, comparing the WLTP to the RDE test collected from real world data,

Page 4 of 9 
the WLTP remains a reasonable predictor of how temperature effects electric vehicle range.

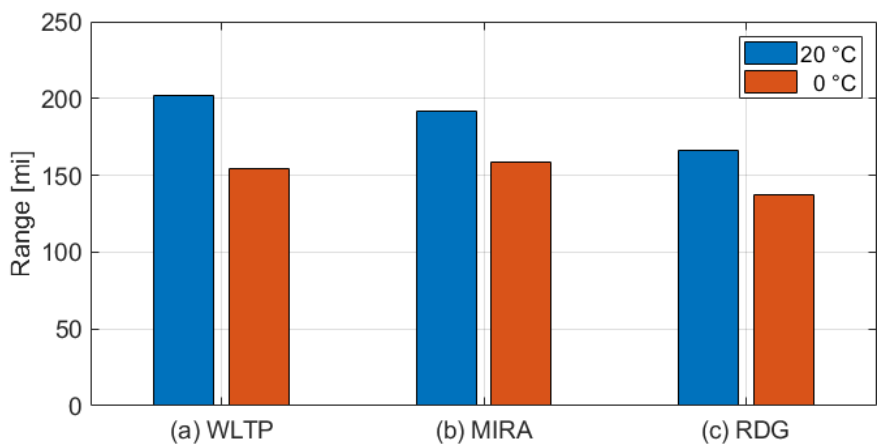

Figure 7. Comparative analysis of vehicle range under various driving cycles at different temperatures.

\section{Li-ion Cell Model Development}

A non-isothermal equivalent circuit cell model has been parameterized from experimental data to undertake cell thermal analysis via simulation. The equivalent circuit model, shown in Figure 8 utilizes a single resistor/capacitor $(R C)$ block to represent electrochemical behavior. The model includes a thermal module for cell temperature dynamics. The following sub-sections present details of model parameter estimation and model validation tasks.

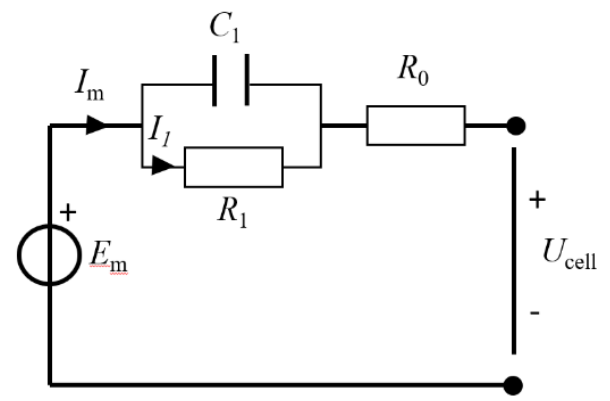

Figure 8. Single $R C$ block equivalent circuit model. Where $E_{\mathrm{m}}$ is the electromotive force of the main branch, $C_{1}$ is the block capacitor, $R_{1}$ is the block resistor, $R_{0}$ is the series resistor, $I_{\mathrm{m}}$ is the current of the main branch, $I_{1}$ is the current of the block branch and $U_{\text {cell }}$ is the cell voltage.

The terminal voltage of the cell is calculated as follows:

where,

$$
U_{\text {cell }}=E_{m}-\left(I_{m} R_{0}\right)-U_{1},
$$

$$
U_{1}=\int\left(\frac{I_{1}}{C_{1}}-\frac{U_{1}}{R_{1} \cdot C_{1}}\right) d t
$$

All circuit elements vary with battery temperature and state of charge. Therefore, each element of the equivalent circuit introduced in Figure 8 is a function of these two variables: $E_{\mathrm{m}}(\mathrm{SoC}, T), R_{0}(\mathrm{SoC}, T)$, $R_{1}(\mathrm{SoC}, T)$ and $C_{1}(\mathrm{SoC}, T)$. In this model, the usable cell capacity (extractable charge) depends solely on cell temperature. Cell aging is not considered in the current work. Hence, cell capacity is:

$$
C_{Q}=C_{Q}(T)
$$

Then, assuming a fully charged cell at $\mathrm{t}=0$, the extracted charge $Q_{e}$ is defined as:

$$
Q_{e}(t)=\int_{0}^{t} I_{m}(\tau) d \tau
$$

The state of charge (SoC) is calculated as:

$$
\operatorname{SoC}=1-Q_{e} / C_{Q} \text {. }
$$

An OCV-SOC correlation curve has been used to apply a corrective factor to SoC calculation. Following the approach presented in [16], the inner cell temperature is assumed to be uniform and taken as the average temperature in the cell. The thermal module of the model consists of the heat equation of a homogeneous body exchanging heat with its environment:

$$
C_{T} \frac{d T}{d t}=-\frac{T-T_{a}}{R_{T}}+P_{S}
$$

Where $C_{T}$ is the cell heat capacitance $\left(\mathrm{J} \mathrm{m}^{-3} \mathrm{~K}^{-1}\right), T$ is the cell temperature $\left({ }^{\circ} \mathrm{C}\right), T_{a}$ is the ambient temperature $\left({ }^{\circ} \mathrm{C}\right), R_{T}$ is the heat transfer coefficient between the cell and its environment (convection resistance, $\mathrm{W} \mathrm{m}^{-2} \mathrm{~K}^{-1}$ ) and $P_{S}$ is the heat generation inside the cell $(\mathrm{W})$. Through Laplace transformation:

$$
T(s)=\frac{P_{S} R_{T}+T_{a}}{1+P_{S} R_{T} s}
$$

The cell under analysis undergoes low current duty cycles (below 2C). This is considered a low C-rate. At low C-rates, it is possible to neglect temperature gradients between cell core temperature and surface (can) temperature [17]. This decision depends on the scope of the study and whether the cell operates under core temperature safety limits or not. Due to the test temperature levels tested in this work, cell surface temperature is considered a good indicator of cell temperature in order to understand aspects such as loss of cell usable capacity due to cold operation. The model has been implemented using Simscape ${ }^{\mathrm{TM}}$. Twodimensional look-up tables are used to consider the dependence of each element on $\mathrm{SoC}$ and temperature using linear interpolation between data points. The thermal module has also been implemented using the foundation library/thermal section of Simscape ${ }^{\mathrm{TM}}$. The total heat dissipated inside the cell is modelled through Joule heating using the voltage drop across the resistive elements $(P=V . I)$. Entropic heat generation is not considered in this work as the relative contribution is small [15].

\section{Model Extraction}

The equivalent circuit elements $\left(E_{\mathrm{m}}(\mathrm{SoC}, T), R_{0}(\mathrm{SoC}, T), R_{1}(\mathrm{SoC}, T)\right.$ and $\left.C_{1}(\mathrm{SoC}, T)\right)$ are parameterized using pulse discharge characterization tests and least squares fitting in MATLAB/Simulink ${ }^{\circledR}$. This method considers both transient and open circuit voltage (OCV) behavior at various cell SoC levels. Moreover, the values of $C_{T}$ (cell heat capacitance) and $R_{T}$ (heat transfer coefficient) can also be obtained through a separate fitting procedure using recorded temperature data.

\section{Experimental Data for Parameter Estimation}

At each temperature level $\left(20^{\circ} \mathrm{C}, 10^{\circ} \mathrm{C}, 0^{\circ} \mathrm{C},-10^{\circ} \mathrm{C},-20^{\circ} \mathrm{C},-30^{\circ} \mathrm{C}\right.$ and $-40^{\circ} \mathrm{C}$ ), the Sony VTC6 cell (fully charged) undergoes partial discharge-rest cycles preceded by an initial rest period of one hour. 
Each pulse involves 6 minutes discharging at $1 \mathrm{C}$ followed by a rest period of one hour (Figure 9a). At the end of each rest period the voltage is considered a good estimate of OCV given its stable value. The discharge-rest cycle continues until the cell reaches its lower voltage cutoff.

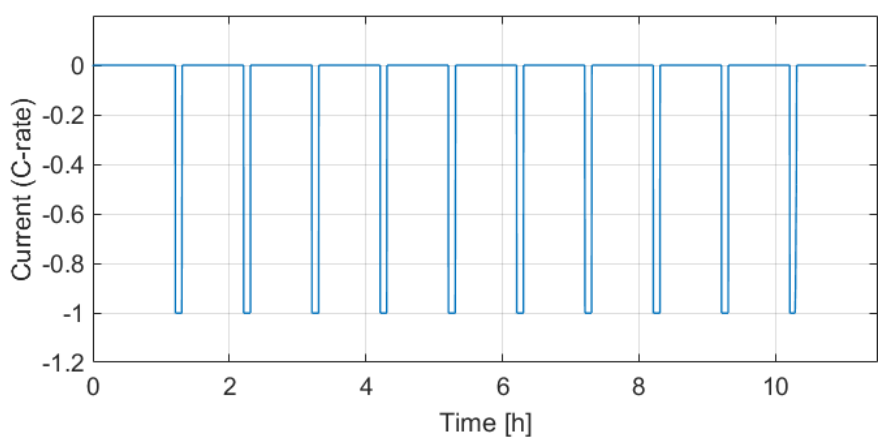

(a)

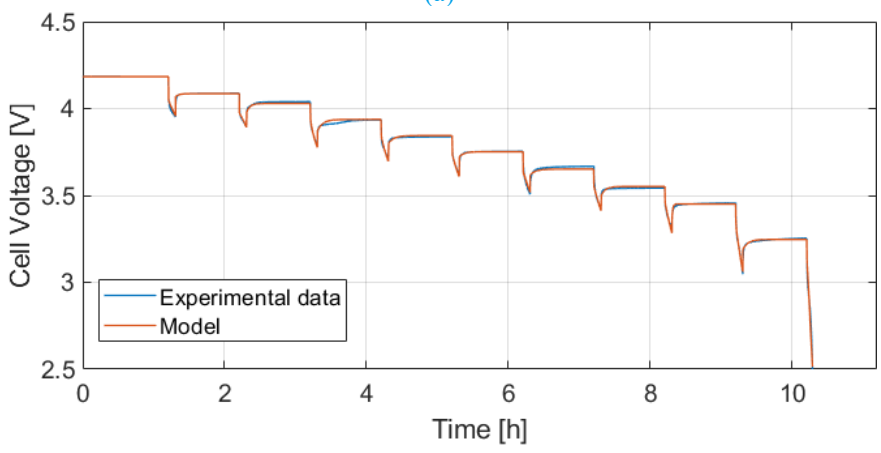

(b)

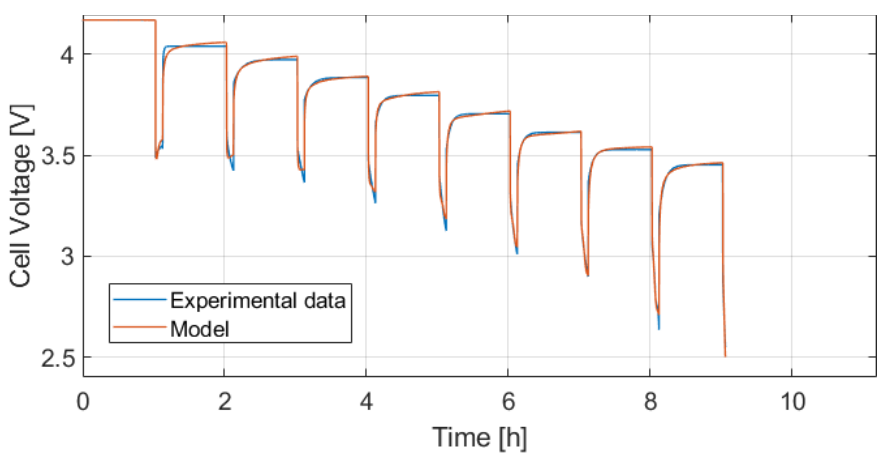

(c)

Figure 9. Characterization tests for fitting of equivalent circuit parameters (a) Current profile, (b) Cell voltage profile at $20^{\circ} \mathrm{C}$ of experimental and fitted model and (c) Cell voltage profile at $-20^{\circ} \mathrm{C}$ of experimental and fitted model.

\section{Parameter Estimation Procedure}

For each test at a fixed temperature, the equivalent circuit parameters were fitted as a 1D lookup table of SoC using a least squares method in Simulink Design Optimization ${ }^{\mathrm{TM}}$. Combining the tests from the different temperatures results in a 2D lookup-table for each circuit element as a function of SoC and temperature. Seven SoC breakpoints have been used $(0 \%, 10 \%, 20 \%, 50 \%, 80 \%, 90 \%$ and $100 \%)$, being slightly focused on high SoC and low SoC to better capture non-linear electrochemical behavior occurring at such stages. In this estimation procedure, cell current is considered as an input and cell voltage is the output. In addition, thermal module parameters were adapted according to information from the Sony VTC6 cell data sheet, as well as previously published results on Sony VTC6 cell thermal properties [18]. To refine the values of heat transfer coefficient between cell and environment and cell heat capacity, the same parameter estimation tool was run again using cell current as the input and cell temperature as the output. Figure $9 \mathrm{~b}$ compares the measured and fitted cell voltage at $20{ }^{\circ} \mathrm{C}$ with a mean voltage error of less than $1.5 \%$. Figure $9 \mathrm{c}$ compares the measured and fitted cell voltage at $-20{ }^{\circ} \mathrm{C}$ with a mean voltage error of less than $3 \%$. Figure 10 shows the state of charge of the cell under discharge pulse duty (Figure 9a) indicated by the fitted model. The example chosen is state of charge variation at $20^{\circ} \mathrm{C}$.

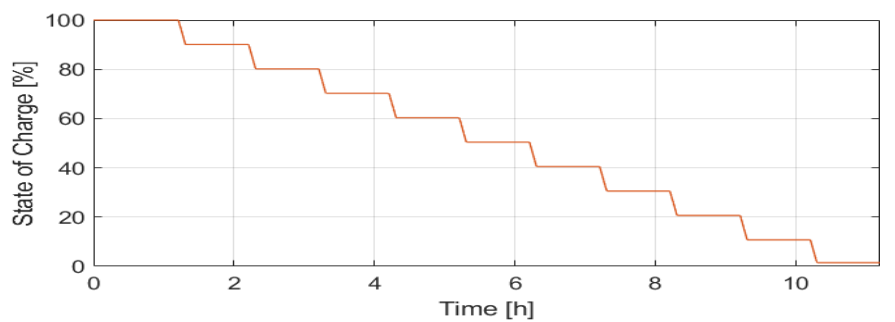

Figure 10. Estimated (model) battery state of charge (SoC) during discharge pulse test at $20^{\circ} \mathrm{C}$.

\section{Model Validation}

To validate the accuracy of the model at high and low temperatures, it is compared to the experimental WLTP data at both $20^{\circ} \mathrm{C}$ and $-20{ }^{\circ} \mathrm{C}$. Figures 11 and 12 show the voltage time profiles under WLTP range tests at $20^{\circ} \mathrm{C}$ and $-20^{\circ} \mathrm{C}$ respectively, as well as corresponding model results.

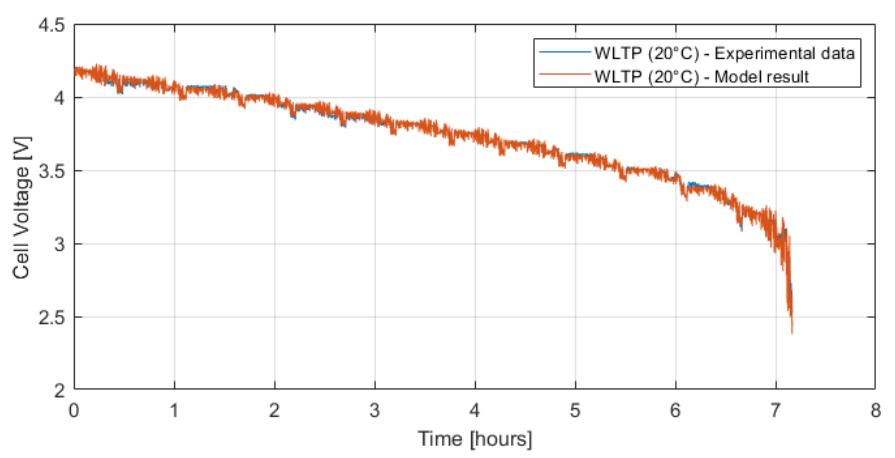

(a) Cell voltage

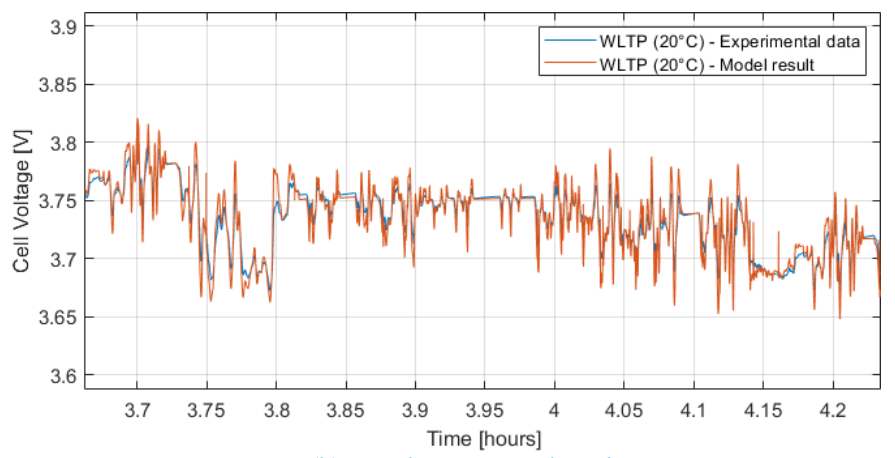

(b) Voltage zoomed section

Figure 11. Cell voltage during WLTP test at $20^{\circ} \mathrm{C}$ vs model simulated voltage.

Page 6 of 9

$10 / 19 / 2016$ 


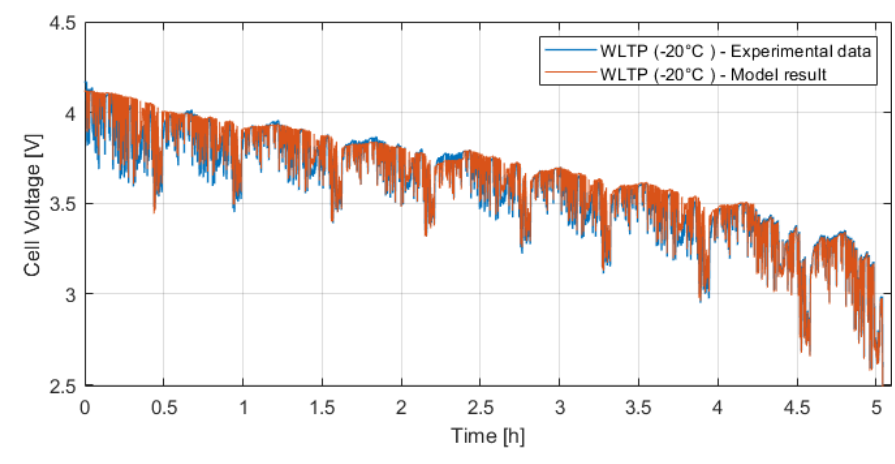

(a) Cell voltage

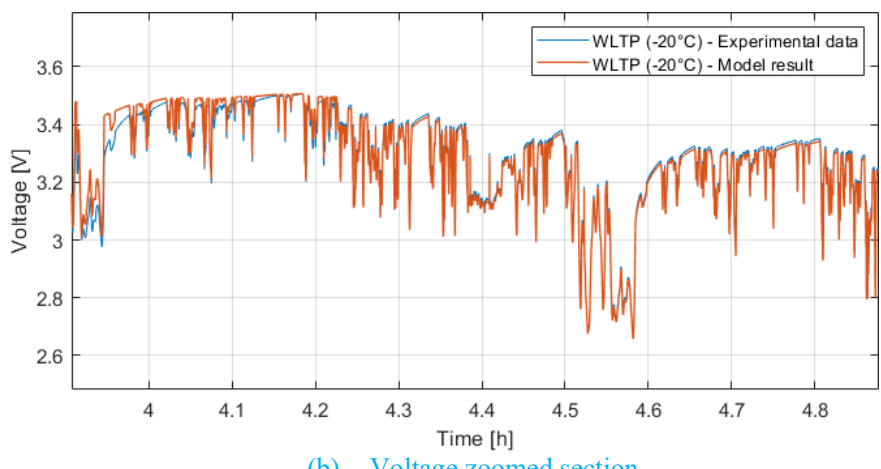

(b) Voltage zoomed section

Figure 12. Cell voltage during WLTP test at $-20^{\circ} \mathrm{C}$ vs model simulated voltage.

At $20^{\circ} \mathrm{C}$, the average model voltage error is $3 \%$ and $-20^{\circ} \mathrm{C}$ the average model error increases to $5 \%$, probably due to cell voltage at $-20^{\circ} \mathrm{C}$ being a profile of slightly higher magnitude and complexity.

To justify the selection of a $1-R C$ equivalent circuit over a $2-R C$ equivalent circuit, the fitting and validation process was repeated at 20 ${ }^{\circ} \mathrm{C}$ and $-20{ }^{\circ} \mathrm{C}$ for a $2-R C$ circuit. The mean voltage error at $-20{ }^{\circ} \mathrm{C}$ was seen to reduce to $3 \%$, a $2 \%$ error improvement, but with a $20 \%$ increase in computational cost. Demonstrating that for the dynamic frequency bandwidth required in this work, the simplified $1-R C$ model provides enough performance. Reducing the required degrees of freedom is also beneficial to multi-cell studies, such as temperature distribution across a pack, which is one potential use of the presented model.

Cell temperature was also analyzed to validate the model. As an example, Figure 13 shows the response of the model during the WLTP cycle simulation at $20{ }^{\circ} \mathrm{C}$ compared with experimental data for the same test. The model error in this case is less than $4 \%$, which is considered appropriate given the $1.1{ }^{\circ} \mathrm{C}$ theoretical error provided by the thermocouples used to measure cell temperature. The following sections utilize the validated model to investigate how changing the battery heat transfer properties and driver behavior influence the cold temperature range of electric vehicles.

\section{Model-based Thermal Analysis}

The cell model has been used to analyze the scope of improvement in vehicle range by managing cell temperature. In this simulation-based study the cell heat transfer coefficient (between the cell and the environment) within the thermal module is adjusted to replicate the effect of cell environment, such as surrounding cells, cooling medium or isolation design techniques.

Page 7 of 9

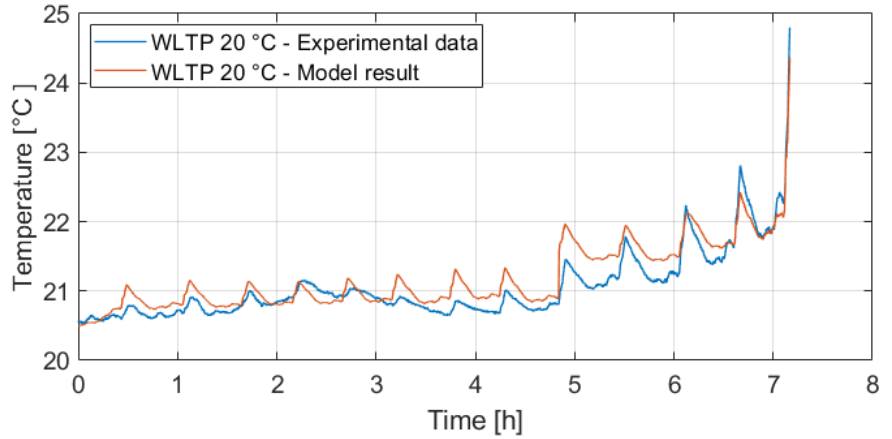

Figure 13. Cell temperature during WLTP test at $20^{\circ} \mathrm{C}$ vs model simulated cell temperature.

The WLTP cycle is used for this study since it has been run at all temperature levels under analysis. Key thermal module parameters of the cell are presented in Table 3:

Table 3. Sony VTC6 cell thermal module parameters

\begin{tabular}{|l|l|}
\hline Property & Value \\
\hline Shape & Cylindrical \\
\hline Diameter & $0.01850 \mathrm{~m}$ \\
\hline Length & $0.06520 \mathrm{~m}$ \\
\hline Heat Transfer Coefficient & $13.45 \mathrm{~W} \mathrm{~m}^{-2} \mathrm{~K}^{-1}$ \\
\hline Heat capacity & $1 \times 10^{3} \mathrm{~J} \mathrm{~m}^{-3} \mathrm{~K}^{-1}$ \\
\hline
\end{tabular}

Figure 14 presents the results of simulating two scenarios: (i) heat transfer coefficient $=0$ (adiabatic), indicating the ideal self-heating scenario where all heat produced remains in the cell, and (ii) heat transfer coefficient tends to infinity (isothermal) simulating all heat produced being lost to the surrounding environment. Both situations are extreme cases and have been considered to estimate the maximum scope of improvement in vehicle range through self-heating, and to identify when external heating is required.

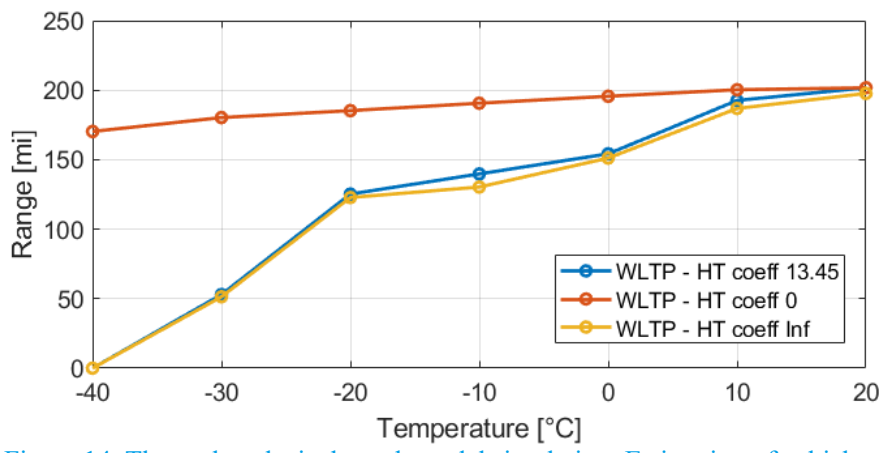

Figure 14. Thermal analysis through model simulation: Estimation of vehicle range under variations of heat transfer coefficient.

From Figure 14, improvements to the thermal management strategy can extend the range of the vehicle up to 170 miles at $-40{ }^{\circ} \mathrm{C}$, through battery self-heating during normal operation. The results also demonstrate the scope for battery external heating and pre-heating at low temperatures during range tests. At $-20{ }^{\circ} \mathrm{C}$ the heat generation from ideal self-heating $(\mathrm{HT}$ coeff $=0$ ) leads to a 185.3-mile range compared to 201.7 miles at $20^{\circ} \mathrm{C}$. If the battery were to be externally pre-heated prior to the test and maintain its temperature, then the maximum range would increase by only $8.1 \%$ compared to the ideal 
self-heating case. Whilst this scenario assumes ideal adiabatic cell conditions, full discharge and does not consider cabin heating, it does demonstrate how vehicle simulations and component-in-the-loop testing can help to inform the automotive development process at an early stage. Figure 15 shows temperature cell profiles under variations of heat transfer coefficient. In this set of simulations, a WLTP cycle is run until cell reaches cut-off voltage limit of $2.5 \mathrm{~V}$ for each temperature level under study. For each temperature level, the heat transfer coefficient is set to zero until the cell reaches a temperature of $20^{\circ} \mathrm{C}$. After that, the heat transfer coefficient ramps up slowly back to theoretical value of $13.45 \mathrm{~W} \mathrm{~m}^{-2} \mathrm{~K}^{-1}$.

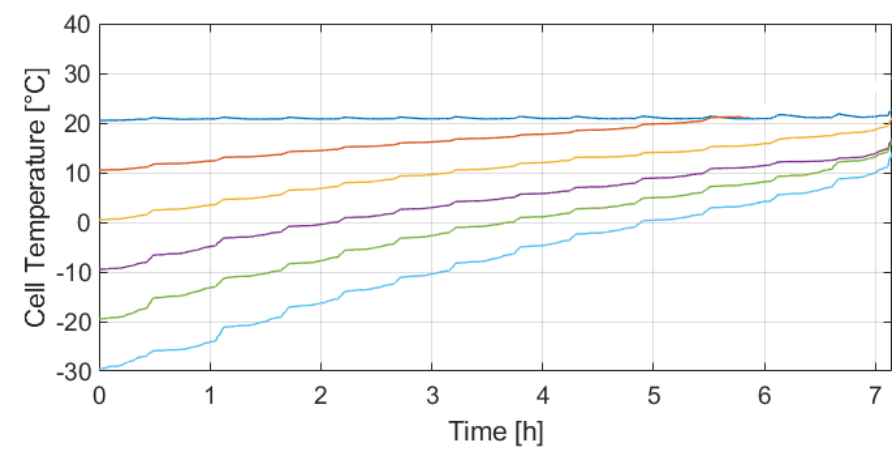

Figure 15. Temperature profiles for WLTP cycle tests at various initial conditions of interest. Towards the end of the simulation the heat transfer coefficient rams up slowly back to theoretical value.

\section{Model-based Driver Analysis}

Following the analysis of cell temperature and its effect on vehicle range, the effect of the driver on normal temperature range $\left(20^{\circ} \mathrm{C}\right)$ and cold start range $\left(-20{ }^{\circ} \mathrm{C}\right)$ is evaluated using the model and three different driver presets, which are pre-established in CarMaker: defensive, normal and aggressive. These driver presets represent different settings for the driver behavior regarding dynamics, energy efficiency and nervousness. The cycle considered in this study is RDG due to its flexibility regarding velocity profile. Figure 16 shows simulation results of variation in range according to the driver behavior. At both temperatures under study the implications of an aggressive driver are appreciated with a decrease in range by $6 \%$ compared to a normal driver, whereas a defensive driver setting causes an improvement in range by $3 \%$.

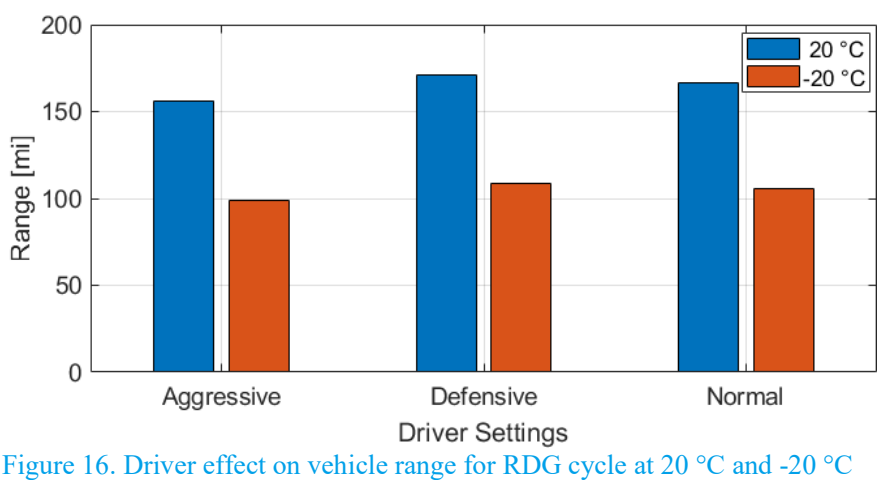

\section{Concluding Remarks}

In this work, a battery-in-the-loop experiment has been set up to estimate and analyze the range of a lithium-ion battery electric vehicle under cold start conditions, both through standardized automotive duty cycles and within simulated 'real-world' driving environment using CarMaker from IPG Automotive. Vehicle range is seen to reduce progressively with temperature, showing significant range reductions below $-20^{\circ} \mathrm{C}$. The range reduction with temperature from the WLTP compares well with simulated driving of GPS data from real driving emissions (RDE) tests.

A simplified non-isothermal equivalent circuit model is parameterized and validated to investigate the scope of self-heating thermal management strategies. This demonstrates that insulated cells and joule heating can provide cold start vehicle range approaching that of $20{ }^{\circ} \mathrm{C}$ ambient temperature, negating ancillary loads. Through varying driver model behavior, it is also shown how driver behavior can influence cold start vehicle range.

Currently, further work on cell thermal management strategies, battery pack design and driver influence on vehicle range is undertaken and will be the subject of future contributions.

\section{References}

1. Ma S., Jiang M., Tao P., Song C., et al., "Temperature effect and thermal impact in lithium-ion batteries: A review", Progress in Natural Science: Materials International, 28(1):653-666, 2018, doi: $10.1016 /$ j.pnsc.2018.11.002.

2. Gao F. and Tang Z., "Kinetic behavior of $\mathrm{LiFePO} 4 / \mathrm{C}$ cathode material for lithium-ion batteries", Electrochimica Acta, 53(15):5071-5075, 2008, doi:10.1016/j.electacta.2007.10.069.

3. Zhang S., Xu K. and Jow T, "The low temperature performance of Li-ion batteries", Journal of Power Sources, 115(1):137-140, 2003, doi:10.1016/S0378-7753(02)00618-3.

4. Cabañero M, Altmann J., Gold L., Boaretto N., et al., "Investigation of the temperature dependence of lithium plating onset conditions in commercial Li-ion batteries", Energy, 171(1): 1217-1228, 2019, doi:10.1016/i.energy.2019.01.017.

5. Petzl M., Kasper M. and Danzer M, "Lithium plating in a commercial lithium-ion battery - A low-temperature aging study", Journal of Power Sources, 275(1):799-807, 2015, doi:10.1016/j.jpowsour.2014.11.065.

6. Mohamad A. and Shabani B., "An Experimental Study of a Lithium Ion Cell Operation at Low Temperature Conditions", Energy Procedia, 110(1): 128-135, 2017, doi:10.1016/j.egypro.2017.03.117.

7. Sun B., Chen Z., Kim H., Ahn H., et al., "MnO/C core-shell nanorods as high capacity anode materials for lithium-ion batteries", Journal of Power Sources, 196(6):3346-3349, 2011, doi:10.1016/j.jpowsour.2010.11.090.

8. Li Y., Li Q., and Tan Z., "A review of electrospun nanofiberbased separators for rechargeable lithium-ion batteries", Journal of Power Sources, 443(1):227-262, 2019, doi:10.1016/j.jpowsour.2019.227262.

9. Costa C., Lee Y., Kim J., Lee S., et al., "Recent advances on separator membranes for lithium-ion battery applications: From porous membranes to solid electrolytes", Energy Storage Materials, 22(1):346-375, 2019, doi:10.1016/j.ensm.2019.07.024.

10. Opra D., Gnedenkov S., and Sinebryukhov S., "Recent efforts in design of TiO2(B) anodes for high-rate lithium-ion batteries: A review", Journal of Power Sources, 442(1):227225, 2019, doi:10.1016/j.jpowsour.2019.227225.

11. Jaguemont, J. Boulon, L. Dubé, Y., “A comprehensive review of lithium-ion batteries used in hybrid and electric vehicles at cold temperatures", Applied Energy, 164, 99-114, 2016.

Page 8 of 9 
12. Ji, Y. Wang C.Y., "Heating strategies for Li-ion batteries operated from subzero temperatures", Electrochimica Acta, 107, 664-674, 2013, doi.org/10.1016/i.electacta.2013.03.147

13. Fan R. Zhang C. Wang Y. Ji C et al., "Numerical study on the effects of battery heating in cold climate", Journal of Energy Storage, 26, 100969, 2019, doi.org/10.1016/j.est.2019.100969

14. Lain, M. Brandon, J. Kendrick, E., "Design Strategies for High Power vs. High Energy Lithium Ion Cells", Batteries, 5, 64, 2019, doi:10.3390/batteries5040064.

15. Berg, H. "Batteries for Electric Vehicles - Materials and Electrochemistry" Cambridge University Press, 2015.

16. Huria T., Ceraolo M., Gazzarri J. and Jackey R., "High fidelity electrical model with thermal dependence for characterization and simulation of high-power lithium battery cells", IEEE International Electric Vehicle Conference, Greenville, SC, 2015, doi: 10.1109/IEVC.2012.6183271.

17. McTurk E., Amietszajew T., Fleming J. and Bhagat R., "Thermoelectrochemical instrumentation of cylindrical Li-ion cells", Journal of Power Sources, 379(1):309-316, 2018, doi: 10.1016/j.jpowsour.2018.01.060.

18. Maleki H., Al Hallaj S., Selman J. Dinwiddie R., et al., "Thermal Properties of Lithium-Ion Battery and Components", Journal of The Electrochemical Society, 146(3):947-954, 1999, doi: $10.1149 / 1.1391704$.

\section{Contact Information}

Dr. Ashley Fly. A.Fly@lboro.ac.uk, Department of Aeronautical and Automotive Engineering, Loughborough University, Loughborough, Leicestershire, United Kingdom.

\section{Acknowledgments}

The authors would like the acknowledge the support of the Advanced Propulsion Centre (APC), United Kingdom.

\section{Definitions/Abbreviations}

$\begin{array}{ll}\text { WLTP } & \begin{array}{l}\text { Worldwide Harmonized } \\ \text { Light Vehicle Test } \\ \text { Procedure }\end{array} \\ \text { RDE } & \text { Real Driving Emissions } \\ \text { RDG } & \text { Real Driving Generated } \\ \text { BCU } & \text { Battery Control Unit }\end{array}$

